\title{
Chemical Constituents from Diospyros discolor Willd. and their Acetylcholinesterase Inhibitory Activity
}

\author{
Norhafizoh Abdul Somat ${ }^{1,2}$, Zaini Yusoff ${ }^{3}$, Che Puteh Osman ${ }^{1,2, *}$
}

\section{Norhafizoh Abdul Somat ${ }^{1,2}$, Zaini Yusoff ${ }^{3}$, Che Puteh Osman ${ }^{1,2, *}$}

${ }^{1}$ Atta-ur-Rahman Institute for Natural Product Discovery, Universiti Teknologi MARA, Cawangan Selangor, Kampus Puncak Alam, 42300 Bandar Puncak Alam, Selangor, MALAYSIA.

${ }^{2}$ Faculty of Applied Sciences, Universiti Teknologi MARA, 40450 Shah Alam MALAYSIA.

${ }^{3}$ Faculty of Applied Sciences, Universiti Teknologi MARA, Cawangan Perlis, Kampus Arau, 02600 Arau, Perlis, MALAYSIA.

\section{Correspondence}

\section{Che Puteh Osman}

Atta-ur-Rahman Institute for Natural Product Discovery, Universiti Teknolog MARA, Cawangan Selangor, Kampus

Puncak Alam, 42300 Bandar Puncak Alam, Selangor; Faculty of Applied Sciences, Universiti Teknologi MARA, 40450 Shah Alam, MALAYSIA.

E-mail: cheputeh@uitm.edu.my

History

- Submission Date: 17-08-2020

- Review completed: 29-09-2020;

- Accepted Date: 01-10-2020.

DOI : 10.5530/pj.2020.12.212

Article Available online http://www.phcogj.com/v12/i6s

Copyright

(C) 2020 Phcogj.Com. This is an open access article distributed under the term of the Creative Commons Attribution 4.0 International license.

\section{ABSTRACT}

Background: Diospyros discolor is commonly known as 'buah mentega' and traditionally used to treat various diseases. Many compounds especially triterpenes in Diospyros sp. were reported to inhibit acetylcholinesterase (AChE) and butyrylcholinesterase enzymes in vitro and in vivo. D. discolor was reported to contain triterpenes, yet to be investigated for their AChE inhibitory activity. D. discolor leaves extract showed high (95.80 $\pm 1.57 \%)$ AChE inhibitory activity at the concentration of $100 \mu \mathrm{g} / \mathrm{mL}$. Objective: The aim of the present study is to identify chemical constituents from D. discolor and their AChE inhibitory activity. Materials and Methods: The leaves and stem barks of $D$. discolor were air dried, powdered and successively extracted using $n$-hexane, dichloromethane and methanol. The solvents were evaporated to obtain dried crude extracts. The compounds were purified using exhaustive chromatographic procedures and their structures were determined by analyses of spectral data. The AChE inhibitory activity was carried out using Ellman's method. Results: A new flavonol, 7,4'-dihydroxy-5,3',5'-trimethoxyflavonol (1), along with five known flavonoids (2-6) and six known triterpenes (7-13) were isolated from the leaves and stem barks of $D$. discolor. Selected compounds were evaluated for AChE inhibitory activity, in which stigmast-4-ene3-one (7) showed the lowest inhibition concentration with an $I_{50}$ value of $11.77 \pm 2.11$ $\mu \mathrm{M}$. Conclusion: A new flavonol (1) and twelve known compounds were identified and characterized. Even though $D$. discolor extracts showed high percent inhibition against AChE enzyme, the isolated compounds showed moderate inhibition.

Keywords: Ebenaceae, Triterpenes, Flavonoid, Acetylcholinesterase.

\section{INTRODUCTION}

Diospyros discolor Willd. (syn. D. blancoi) belongs to the family of Ebenaceae, and it is locally known as 'buah mentega'. D. discolor is used traditionally to treat wounds, snakebites, spider bites, stomachache, diabetes, heart problems, hypertension, dysentery, diarrhea and eczema ${ }^{1}$. D. discolor was reported to have free radical scavenging, anti-diarrheal, antimicrobial, analgesic and anti-inflammatory activities ${ }^{1-5}$. Diospyros sp. are rich in naphthoquinones, triterpenes, followed by flavonoid, naphthalene and coumarin-based groups ${ }^{6,7}$. The triterpenes found in Diospyros sp. were mostly of pentacyclic core especially lupane, ursane and oleanane skeleton ${ }^{6}$. Many triterpenes in Diospyros sp. showed inhibition against acetylcholinesterase (AChE) and butyrylcholinesterase enzymes in vitro and in vivo. $D$. discolor was reported to contain triterpenes, yet to be investigated for their AChE inhibitory activity. $D$. discolor leaves extract showed high acetylcholinesterase (AChE) inhibitory activity with $95.80 \pm 1.57 \%$ inhibition during preliminary screening of selected medicinal plants from Taman Herba Perlis ${ }^{8}$. Therefore, this study is warranted to investigate the chemical constituents from the leaves and stem barks extracts of $D$. discolor and their AChE inhibitory activity.

\section{MATERIALS AND METHODS}

\section{General experimental procedures}

${ }^{1} \mathrm{H}-\mathrm{NMR}$ and APT-NMR spectra were recorded at 500 or $600 \mathrm{MHz}$ and 125 or $150 \mathrm{MHz}$, respectively, using Bruker 500 Ultrashield Plus (Bruker, Switzerland) and Bruker Ascend 600 (Bruker, Switzerland). FTIR-ATR spectra were recorded on FTIR Spectrometer INVENIO (Bruker, Switzerland) The mass spectra were recorded using LCMS/MS QTOF Agilent Technologies 6520 (Agilent, Santa Clara, USA). The absorbance for in-vitro analysis was obtained by Spectrostar Nano spectrometer (BMG Labtech, Germany). The solvents used for extraction and isolation were of analytical grade solvents. The silica gel used were silica gel $60 \mathrm{PF}_{254}$ (1.07747), silica gel 60 (0.040-0.063 mm, 1.09385), silica gel $60 \mathrm{PF}_{254}$ containing gypsum (1.07749), and TLC silica gel 60 $\mathrm{F}_{254}$ aluminium sheets (1.05554). The silica gel and TLC were purchased from Merck (Germany). All chemicals and reagents used for acetylcholinesterase inhibitory activity were purchased from Sigma Aldrich unless stated otherwise.

\section{Plant materials}

The leaves and stem barks of $D$. discolor (syn. $D$. blancoi) were collected from Kuala Nerang, Kedah, Malaysia in March 2016. The plant sample was identified by Dr Shamsul Khamis of Universiti Kebangsaan Malaysia and the voucher specimen 
(PID 210517-13) was deposited at Forest Research Institute Malaysia (FRIM), Kepong, Selangor, Malaysia.

\section{Extraction and isolation}

The fresh plant samples $(3.5 \mathrm{~kg}$ ) were air dried and ground into powder using a hammer mill. The ground samples were extracted successively using $n$-hex, $\mathrm{CH}_{2} \mathrm{Cl}_{2}$ and $\mathrm{MeOH}$ at room temperature. The filtrates were concentrated using rotary evaporator. $n$-Hex stem bark extract (3.38 g) was fractioned by VLC eluted with $n$-hex- $\mathrm{CH}_{2} \mathrm{Cl}_{2}$-EtOAc (n-hex: $\mathrm{CH}_{2} \mathrm{Cl}_{2}, \quad 10: 0 \rightarrow 1: 9, \quad \mathrm{CH}_{2} \mathrm{Cl}_{2}:$ EtOAc, 10:0 $\rightarrow 1: 9$ ) afforded 23 fractions. Fraction A (8-11) was further fractionated using CC eluted with $n$-hex- $\mathrm{CH}_{2} \mathrm{Cl}_{2}$-EtOAc ( $n$-hex: $\mathrm{CH}_{2} \mathrm{Cl}_{2}, 9: 1 \rightarrow 1: 9, \mathrm{CH}_{2} \mathrm{Cl}_{2}$ : EtOAc, 10:0 $\rightarrow 7: 3)$, of which purification of A19-25 using PTLC developed with $n$-hex-acetone (9:1) yielded stigmast-4-en-3-one (7) $(15 \mathrm{mg})$.

$\mathrm{CH}_{2} \mathrm{Cl}_{2}$ stem bark extract $(5 \mathrm{~g})$ was fractionated by VLC eluted with $n$-hex- $\mathrm{CH}_{2} \mathrm{Cl}_{2}-\mathrm{MeOH} \quad\left(n\right.$-hex: $\mathrm{CH}_{2} \mathrm{Cl}_{2}, 1: 9,0: 10, \mathrm{CH}_{2} \mathrm{Cl}_{2}: \mathrm{MeOH}$, $98: 2 \rightarrow 91: 9)$ yielded 15 fractions. Fraction B (5-7) was further fractionated using CC eluted with $n$-hex- $\mathrm{CHCl}_{3}$-EtOAc $\left(n\right.$-hex: $\mathrm{CHCl}_{3}$ : EtOAc, 40:55:5 $\rightarrow 20: 75: 5)$ afforded 31 fractions. Betulin (11) $(50 \mathrm{mg})$ was obtained from the purification of $\mathrm{B} 10$ by using $\mathrm{RC}\left(n\right.$-hex: $\mathrm{CH}_{2} \mathrm{Cl}_{2}$, 1:9). Further purification of B5-8 by using RC eluted with $n$-hex$\mathrm{CHCl}_{3}$ - EtOAc (28.5:70:1.5) yielded a mixture of $\beta$-sitosterol (8) and stigmasterol (9) (5.4 mg).

The crude $\mathrm{MeOH}$ stem bark extract of $D$. discolor was dissolved in $\mathrm{MeOH}$ and subjected to LLE with $\mathrm{Et}_{2} \mathrm{O}$ to reduce tannin. The tannin clumped together, and the remaining solution was filtered and dried. $\mathrm{MeOH}$ stem bark extract ( $14 \mathrm{~g}$ ) was fractionated by VLC eluted with $n$-hex- $\mathrm{CH}_{2} \mathrm{Cl}_{2}$-EtOAc-MeOH ( $n$-hex: $\mathrm{CH}_{2} \mathrm{Cl}_{2}, 1: 9,0: 10, \mathrm{CH}_{2} \mathrm{Cl}_{2}$ : EtOAc, 9:1 $\rightarrow 10: 0$, EtOAc: $\mathrm{MeOH}, 9: 1,8: 2)$ yielded 33 fractions. Fraction $\mathrm{C}$ (9-12) was further fractionated using CC eluted with $n$-hex- $\mathrm{CH}_{2} \mathrm{Cl}_{2}$ EtOAc-MeOH ( $n$-hex: $\mathrm{CH}_{2} \mathrm{Cl}_{2}, 4: 6 \rightarrow 0: 10, \mathrm{CH}_{2} \mathrm{Cl}_{2}:$ EtOAc, 9:1 $\rightarrow 0: 10$, EtOAc: $\mathrm{MeOH}, 9: 1 \rightarrow 8: 2)$. The purification of fraction C46 using PTLC eluted with $n$-hex- $\mathrm{CHCl}_{3}$-EtOAc (1:8:1) yielded betulinic acid (12) (40 $\mathrm{mg})$.

Similar method was used to reduce tannin for $\mathrm{MeOH}$ leaves extract of $D$. discolor to give $27 \mathrm{~g}$ extract. The extract was fractionated by VLC eluted with $n$-hex- $\mathrm{CH}_{2} \mathrm{Cl}_{2}$-EtOAc-MeOH $\left(n\right.$-hex: $\mathrm{CH}_{2} \mathrm{Cl}_{2}, 10: 0 \rightarrow 1: 9, \mathrm{CH}_{2} \mathrm{Cl}_{2}$ : EtOAc, 10:0 $\rightarrow 1: 9$, EtOAc: $\mathrm{MeOH}, 10: 0 \rightarrow 8: 2)$ yielded 27 fractions $(\mathrm{E}-\mathrm{H})$. Fraction E (11-12) was fractionated using Sephadex LH 20 eluted with $\mathrm{MeOH}$ to obtain 4 fractions. Fraction E3 was fractionated by CC eluted with $n$-hex- $\mathrm{CH}_{2} \mathrm{Cl}_{2}-\mathrm{MeOH}$ ( $n$-hex: $\mathrm{CH}_{2} \mathrm{Cl}_{2}, 4: 6 \rightarrow 1: 9, \mathrm{CH}_{2} \mathrm{Cl}_{2}: \mathrm{MeOH}$, 10:0, 9:1). Fraction E3-10 was further purified by PTLC developed with $\mathrm{CHCl}_{3}: \mathrm{MeOH}(97: 3)$ to obtain ursolic acid (13) $(11 \mathrm{mg})$. Fraction $\mathrm{F}$ (13-16) was further fractionated using CC packed with sephadex LH20 and eluted with $\mathrm{MeOH}$. Purification of $\mathrm{F} 5$ by $\mathrm{RC}$ eluted with $\mathrm{CH}_{2} \mathrm{Cl}_{2}-$ EtOAc (10:0 $\rightarrow 7: 3)$ yielded kaempferol (3) (2.9 mg). Fraction G (18-19) was fractionated again with $\mathrm{CC}$ by isocratic elution $\mathrm{CH}_{2} \mathrm{Cl}_{2}: \mathrm{MeOH}$ (9:1) afforded 17 fractions. Purification of G15 by PTLC developed with $\mathrm{CH}_{2} \mathrm{Cl}_{2}: \mathrm{MeOH}(9: 1)$ yielded a mixture of (+)-epicatechin (2) and 7,4'-dihydroxy-5,3'5'-trimethoxyflavonol $(0.8 \mathrm{mg})(\mathbf{1})$. Fraction $\mathrm{H}$ (25-27) was further fractionated using VLC eluted with $\mathrm{CH}_{2} \mathrm{Cl}_{2}-$ $\mathrm{MeOH}(10: 0 \rightarrow 8: 2)$ afforded 18 fractions, in which $\beta$-sitosterol-3-Oglucopyranoside (10) $(14 \mathrm{mg})$ was obtained by recrystallization of H7-9 from $\mathrm{CHCl}_{3}$ and $\mathrm{MeOH}$. Fraction $\mathrm{H} 15$ was subjected to RC eluted with $\mathrm{CH}_{2} \mathrm{Cl}_{2}: \mathrm{MeOH}(9: 1,8: 2)$ to afford astragalin (4) $(30 \mathrm{mg})$. Further purification of H16-18 using RC eluted with $\mathrm{CH}_{2} \mathrm{Cl}_{2}-\mathrm{MeOH}(9: 1 \rightarrow 7: 3)$ followed by reverse phase PTLC developed with $\mathrm{H}_{2} \mathrm{O}-\mathrm{MeOH}(6: 4)$ yielded a mixture of hyperin (5) and isoquercitrin (6) $(20 \mathrm{mg})$.

7,4'-dihydroxy-5,3',5'-trimethoxyflavonol (1), brown powder. UV $(\mathrm{MeOH}) \lambda_{\text {max }}(\log \varepsilon) 284 \mathrm{~nm}$; FTIR-ATR (solid) $\mathrm{V}_{\text {max }}: 1214,1515,1609$,
$1719,3384 \mathrm{~cm}^{-1} .{ }^{1} \mathrm{H}-\mathrm{NMR}\left(600 \mathrm{MHz}, \mathrm{CD}_{3} \mathrm{OD}\right) \delta_{\mathrm{H}} 6.99\left(1 \mathrm{H}, \mathrm{d}, \mathrm{J}_{\mathrm{m}}=1.8\right.$ $\mathrm{Hz}, \mathrm{H}-6), 7.05\left(1 \mathrm{H}, \mathrm{d}, \mathrm{J}_{\mathrm{m}}=1.8 \mathrm{~Hz}, \mathrm{H}-8\right), 7.45$ (2H, s, H-2' \& H-6'), 3.90 $\left(6 \mathrm{H}, \mathrm{s}, 3 \mathrm{\prime} / 5^{\prime}-\mathrm{OCH}_{3}\right), 3.81\left(3 \mathrm{H}, \mathrm{s}, 5-\mathrm{OCH}_{3}\right)$. APT-NMR $(150 \mathrm{MHz}$, $\left.\mathrm{CD}_{3} \mathrm{OD}\right) \delta_{\mathrm{C}} 143.0(\mathrm{C}-2), 172.4(\mathrm{C}-4), 149.1$ (C-5), 106.4 (C-6), 167.5 (C-7), 112.0 (C-8), 152.1 (C-9), 40.8 (C-10), 120.2 (C-1'), 108.8 (C2'/6'), $149.2\left(\mathrm{C}-3^{\prime} / 5^{\prime}\right), 166.2\left(\mathrm{C}-4^{\prime}\right), 56.9\left(3^{\prime} / 5^{\prime}-\mathrm{OCH}_{3}\right), 56.7\left(5-\mathrm{OCH}_{3}\right)$; HRESIMS m/z $361.3316[\mathrm{M}+\mathrm{H}]^{+}$(cald 360.31004 for $\mathrm{C}_{18} \mathrm{H}_{16} \mathrm{O}_{8}$ ).

\section{Acetylcholinesterase inhibitory activity}

The extracts and compounds were dissolved in DMSO and phosphate buffers $(0.1 \mathrm{M}, \mathrm{pH}$ 7.4). The reaction mixture consisted of phosphate buffer $(140 \mu \mathrm{L})$, sample $(20 \mu \mathrm{L})$ and AChE enzymes $(20 \mu \mathrm{L}, 0.09 \mathrm{U} /$ $\mathrm{mL})$ was pre-incubated at room temperature for 15 minutes. Then, 5,5-dithiobis (2-nitrobenzoic) acid ( $10 \mu \mathrm{L}, 10 \mathrm{mM}$ ) and acetylthiocholine iodide $(10 \mu \mathrm{L}, 14 \mathrm{mM})$ were added and incubated again for further 15 minutes. The formation of coloured product was measured at 412 $\mathrm{nm}$ using 96-well microplate reader. Compounds having more than $50 \%$ inhibition were further evaluated at different concentrations to determine its half maximal inhibitory concentration $\left(\mathrm{IC}_{50}\right)^{9}$.

\section{Statistical analysis}

The AChE inhibitory activity data were expressed as mean \pm standard deviation. All the data were subjected to one-way analysis of variance (ANOVA) completed with Tukey's post hoc test and $\mathrm{p}<0.05$ was considered as statistically significant using IBM SPSS Statistic version 20. The $\mathrm{IC}_{50}$ was obtained by plotting nonlinear-regression curve of percentage AChE inhibitory activity against logarithm of compound concentration using GraphPad Prism statistical software version 6.01.

\section{RESULTS AND DISCUSSION}

Phytochemical study on the leaves and stem barks of $D$. discolor yielded a new flavonol (1), five known flavonoids (2-6) and seven known triterpenes (7-13) (Figure 1). The known compounds were identified as (+)-epicatechin (2), kaempferol (3), astragalin (4), hyperin (5), isoquercitrin (6), stigmast-4-en-3-one (7), mixture of $\beta$-sitosterol (8) and stigmasterol (9), $\beta$-sitosterol-3-O-glucopyranoside (10), betulin (11), betulinic acid (12), and ursolic acid (13) ${ }^{10-17}$.

A new flavonol (1) was obtained along with compound (2) as a mixture in the form of brown powder. A molecular formula of $\mathrm{C}_{18} \mathrm{H}_{16} \mathrm{O}_{8}$ was generated from LC-MS QTOF with its $[\mathrm{M}+\mathrm{H}]^{+}$at $\mathrm{m} / z 361.3316$ (cald 361.3179 for $\mathrm{C}_{18} \mathrm{H}_{16} \mathrm{O}_{8}$ ). The FTIR-ATR spectrum showed a broad peak of hydroxyl $(\mathrm{O}-\mathrm{H})$ at $3384 \mathrm{~cm}^{-1}$, a strong peak of carbonyl $(\mathrm{C}=\mathrm{O})$ at $1719 \mathrm{~cm}^{-1}$, medium peak of aromatic $(\mathrm{C}=\mathrm{C})$ at $1609 \mathrm{~cm}^{-1}$ and a strong peak of C-O stretch at $1214 \mathrm{~cm}^{-1}$.

The ${ }^{1} \mathrm{H}-\mathrm{NMR}$ spectrum revealed three aromatic proton signals. A pair of meta-coupled signals resonated at $\delta_{\mathrm{H}} 6.99(1 \mathrm{H}, d, J=1.8 \mathrm{~Hz})$ and $7.05(1 \mathrm{H}, d, J=1.8 \mathrm{~Hz})$ assignable as $\mathrm{H}-6$ and $\mathrm{H}-8$ of ring $\mathrm{A}$. A singlet aromatic proton signal at $\delta_{\mathrm{H}} 7.45$ integrated for two protons was assigned as $\mathrm{H}-2^{\prime}$ and $\mathrm{H}-6$ ' of ring B. A singlet appeared at $\delta_{\mathrm{H}} 3.90$ integrated for six protons is assigned to two methoxy protons at C- 3 ' and C-5' of ring B while another singlet signal at $\delta_{\mathrm{H}} 3.81$ is attributed to methoxy protons at $\mathrm{C}-5$ of ring $\mathrm{A}$. The integration of methoxy protons and aromatic protons of ring $\mathrm{B}$ suggesting these protons are arranged in symmetrical manner. The APT-NMR spectrum displayed 14 carbon signals including two signals of methoxy carbon at $\delta_{\mathrm{C}} 56.7\left(5-\mathrm{OCH}_{3}\right)$ and $56.9\left(3^{\prime} / 5^{\prime}-\mathrm{OCH}_{3}\right)$, three signals of methine carbon at $\delta_{\mathrm{C}} 106.4$ (C-6), $112.0(\mathrm{C}-8)$ and $108.8\left(\mathrm{C}-2^{\prime} / 6^{\prime}\right)$ and nine signals of quaternary carbons. Carbonyl carbon was observed at $\delta_{\mathrm{C}} 172.4$ (C-4) while C-9 was observed at $\delta_{C} 152.1$. The chemical shift for C-3 was not detected. The absence of typical singlet aromatic proton signal assignable at C-3 as well as chemical shift value for C-2 suggesting this compound is of flavonol moiety ${ }^{18}$. 
<smiles>COc1cc(C2Oc3cc(O)cc(OC)c3C(=O)C2O)cc(OC)c1O</smiles><smiles>Oc1cc(O)c2c(c1)OC(c1ccc(O)c(O)c1)C(O)C2</smiles><smiles></smiles>

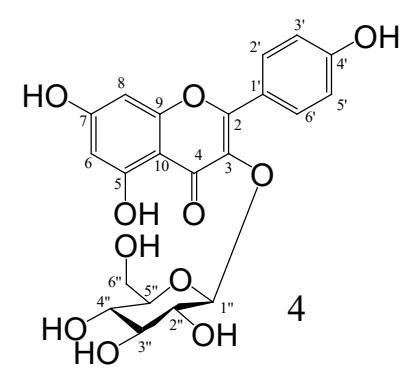

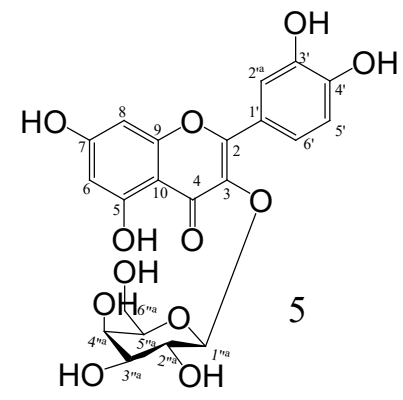<smiles>O=C1Oc2cc(O)cc(O)c2C(=O)C1Oc1ccc(O)c(O)c1</smiles>

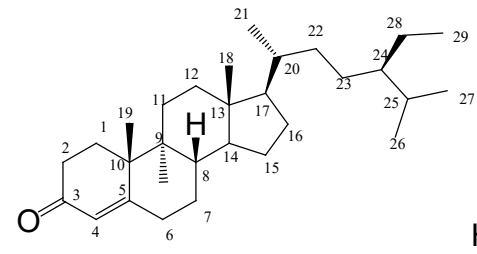

7

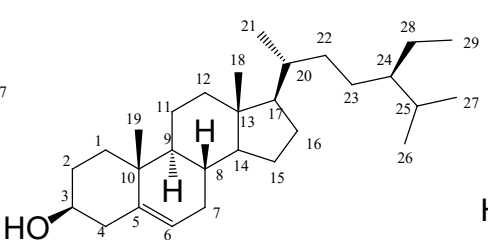

8

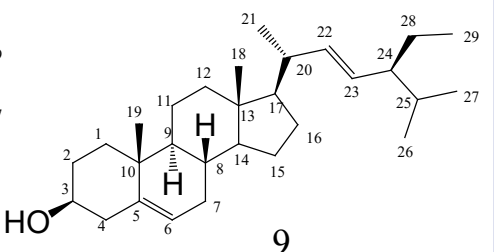

9

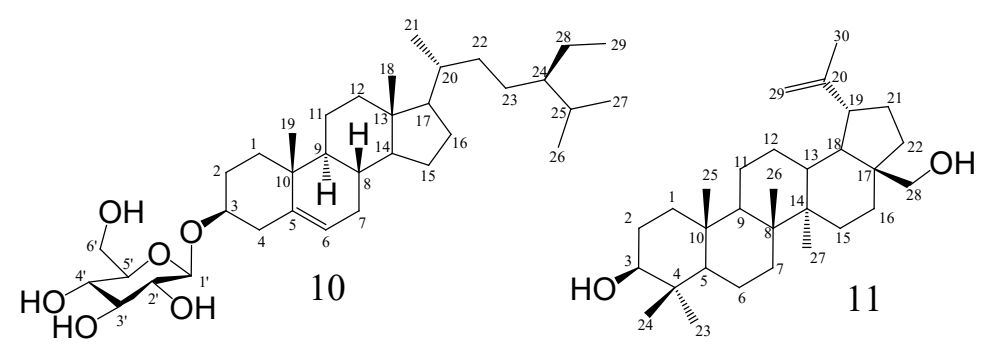

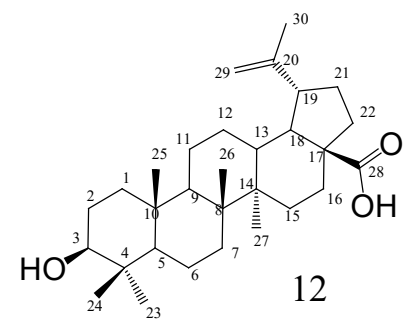

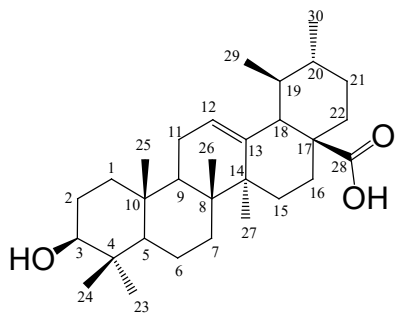

13

Figure 1: Chemical structures from $D$. discolor.

The assignment of $\mathrm{H}-8$ of ring A was confirmed based on its HMBC correlations to $\mathrm{C}-7$ and $\mathrm{C}-10$ while the placement of $\mathrm{H}-6$ was determined based of its HMBC correlations to C-5, C-7 and C-10. The hydroxyl group is located at C-7 based on HMBC cross peaks between $\mathrm{H}-6$ and $\mathrm{H}-8$ with C-7. Meanwhile the methoxy group was assigned to $\mathrm{C}-5$ based on correlations observed between $\mathrm{H}-6$ and $\mathrm{C}-5$. The singlet proton signal of $\mathrm{H}-2^{\prime} / 6^{\prime}$ showed HMBC cross peaks with C-1', C-2, C-3'/5' and C-4' which confirmed their placement at ring $\mathrm{B}$. The connection of ring $\mathrm{B}$ to ring $\mathrm{C}$ was deduced based on $\mathrm{HMBC}$ correlations of $\mathrm{H}-2^{\prime} / 6^{\prime}$ to $\mathrm{C}-\mathrm{1}^{\prime}$ and C-2. Two methoxy groups were assigned at C-3' and C-5' by observing HMBC cross peaks of H-2' and H-6' with C-3' and C-5'. The location of hydroxyl group at C-4' was confirmed based on ${ }^{3} J$ correlations of $\mathrm{H}-2^{\prime}$ and $\mathrm{H}-6$ ' with C-4'. Even though no HMBC correlation was observed to confirm the assignment of $\mathrm{C}-4$ and $\mathrm{C}-9$ at ring $\mathrm{C}$, their chemical shift values are quite typical of flavonol moiety ${ }^{19}$. Close inspection of all spectroscopic data confirmed that compound $\mathbf{1}$ is 7,4'-dihdroxy-5, 3'5'-trimethoxyflavonol.

A flavonoid (4) and six triterpenes (7-12) from the leaves and stem barks of $D$. discolor were examined for AChE inhibitory activity. All the compounds exhibited positive AChE inhibitory activity at $10 \mu \mathrm{M}$ concentration, but only stigmast-4-en-3-one (7) showed inhibition of more than $50 \%$ (Table 1 ). When evaluated for AChE inhibitory activity 
Table 1: Acetylcholinesterase (AChE) Inhibitory Activity of Isolated Compounds.

\begin{tabular}{ccc}
\hline Compounds & \% AChE inhibition at $10 \mu \mathrm{M}^{*}$ & $\mathrm{IC}_{50} \mu \mathrm{M}^{* *}$ \\
\hline Astragalin (4) & $34.57 \pm 1.42^{\mathrm{c}}$ & n.d. \\
Stigmast-4-en-3-one (7) & $51.77 \pm 1.05^{\mathrm{b}}$ & $11.77 \pm 2.11$ \\
$\beta$-sitosterol (8) \& stigmasterol (9) & $20.52 \pm 1.43^{\mathrm{d}, \mathrm{e}}$ & n.d. \\
$\beta$-sitosterol-3-O-glucopyranoside (10) & $15.58 \pm 3.21^{\mathrm{e}}$ & n.d. \\
Betulin (11) & $30.13 \pm 0.46^{\mathrm{c}, \mathrm{d}}$ & n.d. \\
Betulinic acid (12) & $32.48 \pm 1.79^{\mathrm{c}, \mathrm{d}}$ & n.d. \\
Physostigmine & $100 \pm 0.24^{\mathrm{a}}$ & $0.008 \pm 0.004$ \\
\hline
\end{tabular}

Data were expressed as mean \pm standard deviation where $\left({ }^{\star} n=3\right.$ or $\left.{ }^{\star *} n=9\right)$, n.d. $=$ not determined. Data with different superscript lower letter are significantly different $(\mathrm{p}<0.05)$

in dose-dependent manner, it gave an $\mathrm{IC}_{50}$ value of $11.77 \pm 2.11 \mu \mathrm{M}$. Some of the compounds isolated in the present study showed moderate inhibition concentration against AChE. ${ }^{20,21}$ while kaempferol (3) and B-sitosterol-3-O-glucopyranoside (10) were previously reported to have low inhibition concentration against $\mathrm{AChE}^{20,22,23}$.

\section{CONCLUSIONS}

D. discolor (syn. D. blancoi) was found to inhibit AChE during random screening. Phytochemical study on the leaves and stem barks of $D$. discolor yielded a new flavonol, 7,4'-dihydroxy-5,3',5'trimethoxyflavonol (1) along with five known flavonoids and six known triterpenes. The compounds examined for AChE inhibitory activity showed moderate inhibiton concentration except for stigmast4-en-3-one (7). It is postulated that the AChE inhibitory activity of the extract of $D$. discolor is due to synergistic effect of the phytochemicals collectively.

\section{CONFLICTS OF INTEREST}

None.

\section{ACKNOWLEDGEMENT}

This work was supported by the LESTARI (600-IRMI 5/3/LESTARI (027/2019) provided by Universiti Teknologi MARA.

\section{REFERENCES}

1. Howlader MSI, Sayeed MS, Ahmed MU. Characterization of chemical groups and study of Antioxidant, antidiarrhoeal , antimicrobial and cytotoxic activities of ethanolic extract of Diospyros blancoi (Family: Ebenaceae) Leaves. Journal of Pharmacy Research. 2012;5:3050-2.

2. Lee JH, Lee YB, Seo WD, Kang ST, Lim JW, Cho KM. Comparative Studies of Antioxidant Activities and Nutritional Constituents of Persimmon Juice (Diospyros kaki L. cv. Gapjubaekmok). Prev Nutr Food Sci. 2012;17:141-51.

3. Khan MA, Rahman MM, Sardar MN. Comparative investigation of the free radical scavenging potential and anticancer property of Diospyros blancoi (Ebenaceae). Asian Pacific Journal of Tropical Biomedicine. 2016:6:410-7.

4. Akter S, Sarker A. Antimicrobial activities of seeds of Diospyros blancoi and Baccuarea ramiflora. International Journal of Advances in Pharmacy, Biology and Chemistry. 2015;4:789-93.

5. Akter S, Majumder T, Karim R, Ferdous Z, Mohasin S. Analgesic activities of Geodorum densiflorum, Diospyros blancoi, Baccaurea ramiflora and Trichosanthes dioica. Journal of Pharmacognosy and Phytochemistry. 2015;4:209-14
6. Mallavadhani UV, Panda AK, Rao YR. Pharmacology and Chemotaxonomy of Diospyros. Phytochemistry. 1998;49:901-51.

7. Rauf A, Uddin G, Patel S. Diospyros, an under-utilized, multi-purpose plant genus: A review. Biomedicine \& Pharmacotherapy 2017;91:714-30.

8. Abdul Somat N, Osman CP, Ismail NH, Yusoff Z, Md Yusof Y. Screening of Medicinal Plants from Taman Herba Perlis for Acetylcholinesterase Inhibitory Activity. Science Letters. 2019;13:23-32.

9. Jamila N, Khairuddean M, Yeong KK, Osman H, Murugaiyah V. Cholinesterase inhibitory triterpenoids from the bark of Garcinia hombroniana. Journal of Enzyme Inhibition and Medicinal Chemistry. 2015;30:133-9.

10. Abd El-Razak MH. NMR Assignments of Four Catechin Epimers. Asian Journa of Chemistry. 2007;19:4867-72

11. Singh R, Singh B, Singh S, Kumar N, Kumar S, Arora S. Anti-free radical activities of kaempferol isolated from Acacia nilotica (L.) Willd. Ex. Del. Toxicology in Vitro. 2008;22:1965-70.

12. Wei Y, Xie Q, Fisher D, Sutherland IA. Separation of patuletin-3-O-glucoside, astragalin, quercetin, kaempferol and isorhamnetin from Flaveria bidentis (L.) Kuntze by elution-pump-out high-performance counter-current chromatography. Journal of Chromatography A. 2011;1218:6206-11.

13. Estork DM, Gusmao DF, Paciencia ML. First chemical evaluation and toxicity of Casinga-cheirosa to Balb-c male mice. Molecules. 2014;19:3973-87.

14. Estork. - 2014 - First chemical evaluation and toxicity of casinga-cheirosa to balb-c male mice(2).pdf>

15. Khatun M, Billah M, Quader A. Sterols and Sterol Glucoside from Phyllanthus Species. Dhaka Univ J. Sci. 2012;60:5-10.

16. Tijjani A, Ndukwe IG, Ayo RG. Isolation and characterization of lup-20(29)-ene3,28-diol (betulin) from the stem bark of Adenium obesum (Apocynaceae) Tropical Journal of Pharmaceutical Research. 2012;11:259-62.

17. Uddin G, Siddiqui BS, Alam M, Sadat A. Chemical Constituents and Phytotoxicity of Solvent Extracted Fractions of Stem Bark of Grewia optiva Drummond ex Burret. Middle-East Journal of Scientific Research. 2011;8:85-91.

18. Feng $\mathrm{W}$, Hao Z, Li M. Isolation and Structure Identification of Flavonoids. Flavonoids - From Biosynthesis to Human Health: IntechOpen; 2017:17-43.

19. Kim H, Moon BH, Ahn JH, Lim Y. Complete NMR Signal Assignments of Flavonol Derivatives. Magnetic Resonance in Chemistry. 2006;44:188-90.

20. Ali M, Muhammad S, Shah MR. Neurologically potent molecules from Crataegus oxyacantha; isolation, anticholinesterase inhibition, and molecular docking. Frontiers in Pharmacology. 2017;8:1-11.

21. Nguyen DH, Seo UM, Zhao BT. Ellagitannin and flavonoid constituents from Agrimonia pilosa Ledeb. with their protein tyrosine phosphatase and acetylcholinesterase inhibitory activities. Bioorganic Chemistry. 2017:72:293-300.

22. Gade S, Rajamanikyam M, Vadlapudi V. Acetylcholinesterase inhibitory activity of stigmasterol \& hexacosanol is responsible for larvicidal and repellent properties of Chromolaena odorata. Biochimica et Biophysica Acta. 2017;1861:541-50.

23. Balkis A, Tran K, Lee YZ, Ng K. Screening Flavonoids for Inhibition of Acetylcholinesterase Identified Baicalein as the Most Potent Inhibitor. Journal of Agricultural Science. 2015:7:26-35. 


\section{GRAPHICAL ABSTRACT}

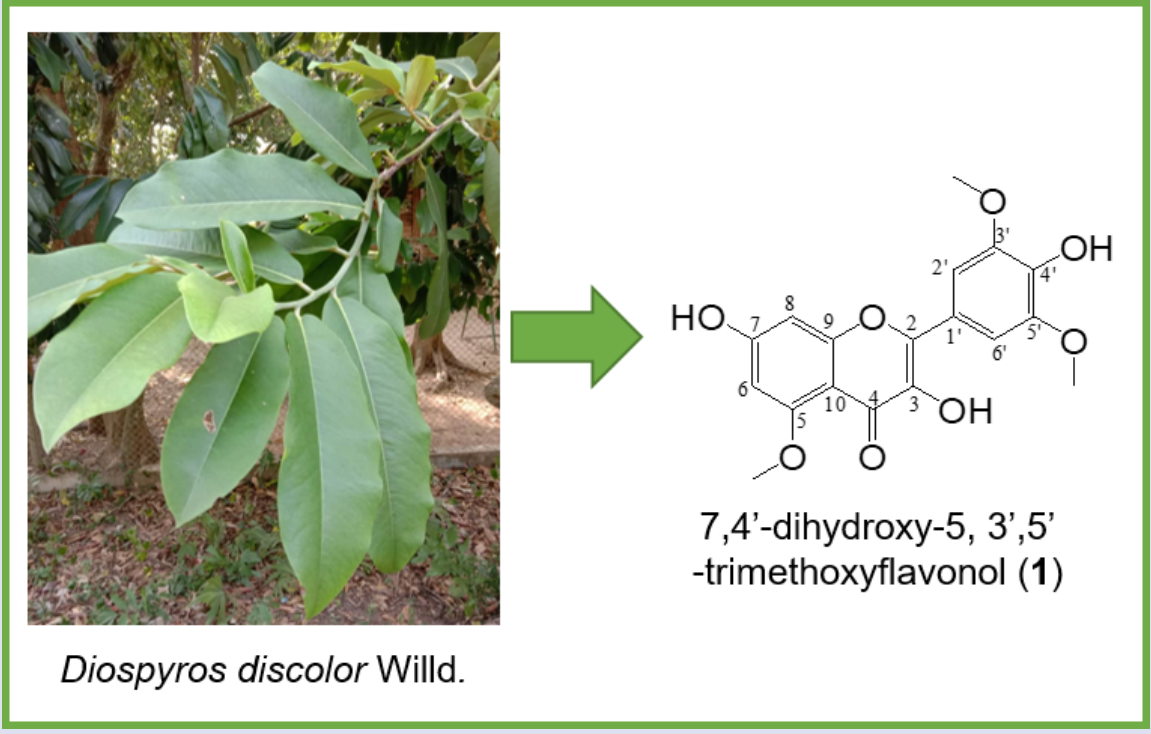

\section{ABOUT AUTHORS}

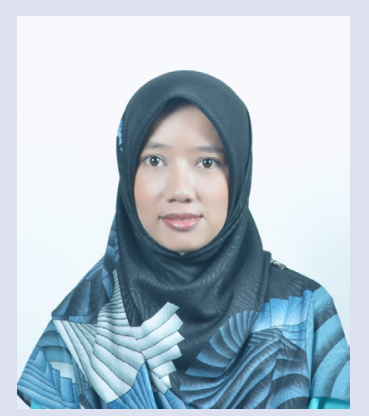

Norhafizoh Abdul Somat is a master student of Faculty of Applied Sciences, Universiti Teknologi MARA, Shah Alam, Malaysia and conducts her research in Atta-ur-Rahman Institute for Natural Product Discovery, Universiti Teknologi MARA, Cawangan Selangor, Malaysia. She obtained her BSc (Hons.) Chemistry from Faculty of Applied Sciences, Universiti Teknologi MARA, Cawangan Perlis, Malaysia. Her research is focused on the chemical constituents from Diospyros discolor and its acetylcholinestrase inhibitory activity.

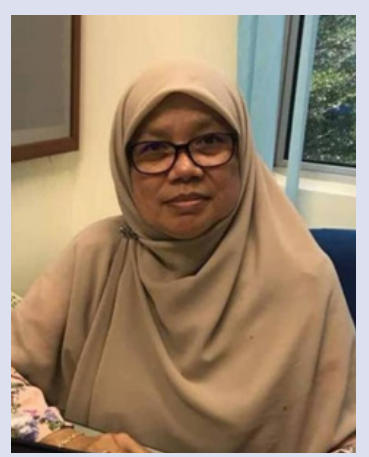

Zaini Yusoff is a former senior lecturer in Phytochemistry as well as Chemical Analysis at Faculty of Applied Sciences, Universiti Technologi MARA, Cawangan Perlis. She obtained both her bachelor's degree and MSc (Chemistry) from Western Illinois University, Macomb, ILL, USA. She was actively involved in research in the field of natural product chemistry prior to her retirement.

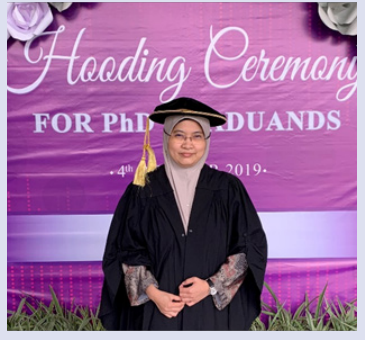

Che Puteh Osman is a research fellow at Atta-ur-Rahman Institute for Natural Product Discovery and a senior lecturer at Faculty of Applied Sciences, Universiti Teknologi MARA, Malaysia. She obtained BSc (Hons.) Applied Chemistry and PhD in natural product chemistry from Universiti Teknologi MARA. Her research areas are bioactive metabolites from plants and optimization of hit compounds as potential bioactive agents.

Cite this article: Somat NA, Yusoff Z, Osman CP. Chemical Constituents from Diospyros discolor Willd. and their Acetylcholinesterase Inhibitory Activity. Pharmacogn J. 2020;12(6)Suppl:1547-51. 